\title{
CRISE DO ROMANCE - CRISE DE UM PAÍS: BERLIN ALEXANDERPLATZ, DE ALFRED DÖBLIN
}

\author{
Willi Bolle ${ }^{1}$ \\ Universidade de São Paulo (USP)
}

RESUMO

A obra principal de Döblin, publicada em 1929, é analisada simultaneamente como um romance de formação e uma epopeia moderna. Ao acompanhar o caminho de vida do protagonista Franz Biberkopf, passamos a conhecer a praça central que simboliza a capital da Alemanha. A metrópole moderna é apresentada através de uma montagem de elementos múltiplos, em que se destacam os botecos como lugares de encontro e os jornais, proporcionando uma imersão na atmosfera social e política da República de Weimar, na época da grande crise econômica de 1929, que acabou levando o país para a ditadura nazista. Paralelamente aos crimes cotidianos comuns, nos quais se envolve também o protagonista, são evocados os crimes na esfera política. A narração do assassinato de uma moça tem como pano de fundo a visão de um ataque aéreo, sugerindo que a guerra de 1914-1918 teria continuidade numa segunda guerra mundial. Com base no principal traço de caráter de Franz Biberkopf - a burrice, ligada à soberba e à ingenuidade - é estabelecida uma analogia com a burrice de um povo, descrita por Robert Musil, em 1937. A análise termina com uma discussão crítica da postura moralizante do narrador de Döblin.

\section{ABSTRACT}

Döblin's mainwork, published in 1929, is considered simultaneously as a Bildungsroman and as a modern epos. By following the way of life of the protagonist Franz Biberkopf, we get to know the central square which symbolizes the capital of Germany. The modern metropolis is described through a montage of multiple elements, especially the bars as meeting places and the newspapers, providing an immersion into the social and political atmosphere of the Republic of Weimar, at the time of the big economic crisis of 1929, which at the end conducted the country into dictatorship. In comparison with the costumary daily crimes, in which also the protagonist is involved, are evoqued the crimes in the political sphere. The murder of a young woman is narrated showing in the background an air raid, suggesting that the big war of 1914-1918 would have a continuation in a second world war. Based on the main characteristic of Franz Biberkopf - his stupidity, together with arrogance and ingenuity - is shown an analogy with the stupidity of people, as described by Robert Musil in 1937. This study ends with a critical analysis of the moralizing atitude of Döblin's narrator.

\author{
PALAVRAS-CHAVE: \\ Alfred Döblin; \\ Berlin Alexanderplatz; \\ romance de \\ formação; \\ epopeia moderna; \\ metrópole; \\ República de \\ Weimar.
}

\footnotetext{
1 Professor do Departamento de Letras Modernas, Faculdade de Filosofia, Letras e Ciências Humanas, Universidade de São Paulo. E-mail: willibolle@yahoo.com.
} 
A

fred Döblin (1878-1957) é, ao lado de Franz Kafka, Bertolt Brecht, Thomas Mann e Robert Musil, um dos principais escritores de língua alemã do século XX. Durante a República de Weimar, ele foi uma das personalidades mais importantes da cena literária alemã. Depois da tomada do poder pelos nacional-socialistas, Döblin saiu da Alemanha para o exílio, retornando somente após o término da Segunda Guerra Mundial. A sua obra Berlin Alexanderplatz, publicada em 1929,2 é a principal contribuição alemã à literatura universal, enquanto retrato da metrópole moderna com os meios da ficção. Ela inspirou um filme, em 1931, dirigido por Piel Jutzi e, em 1979/1980, um seriado de televisão, produzido por Rainer Werner Fassbinder.

\section{Romance de formação ou epopeia moderna?}

Esta questão, que é fundamental para a interpretação do livro publicado por Döblin em 1929, foi levantada por Walter Benjamin em sua resenha intitulada "Crise do romance" (1930): "Por que o livro se chama Berlin Alexanderplatz, enquanto A história de Franz Biberkopf só aparece como subtítulo?" 3 Como será explicado, a obra tem dois eixos de composição que estão entrelaçados. Enquanto história de um indivíduo chamado Franz Biberkopf, o livro filia-se à tradição do gênero romance, especificamente do romance de formação. Ao mesmo tempo, ao escolher Alexanderplatz a praça emblemática da capital da Alemanha - como lugar central do enredo e como cenário da história desse país, num de seus momentos cruciais, o autor reatualiza o gênero antigo da epopeia, que focaliza a história de um povo. O próprio Döblin, num retrospecto em 1932, referese ao seu livro como "obra épica", reiterando a sua concepção de escrita que ele tinha explicado numa conferência de 1928, intitulada "A construção da obra épica". ${ }^{4}$ Analisaremos aqui o livro Berlin Alexanderplatz simultaneamente nos seus dois níveis de composição.

\footnotetext{
2 Usei aqui a edição Berlin Alexanderplatz, Munique: dtv, 1965; e a tradução de Irene Aron, São Paulo: Martins Fontes, 2009. A esta versão brasileira referem-se daqui em diante todas as citações que vêm acompanhadas apenas da indicação da(s) página(s). - Nesta e nas demais traduções do alemão aqui citadas tomei a liberdade de fazer às vezes algumas alterações.

${ }^{3}$ W. Benjamin, "Crise do romance: Sobre Berlin Alexanderplatz, de Döblin", In: Obras Escolhidas I. São Paulo: Brasiliense, 1985, p. 57.

${ }^{4}$ A. Döblin, "Der Bau des epischen Werkes", in: Die Neue Rundschau 4 (1929), p. 527-551. Características épicas marcam também várias outras obras do autor: Die drei Sprünge des Wang-
} 
No prólogo, o narrador nos introduz à história do operário Franz Biberkopf, que acaba de sair da cadeia. Ele cumpriu uma pena de quatro anos, por ter matado, num ataque de raiva, a sua noiva. Ao procurar retomar as suas atividades cotidianas, ele se propõe "levar uma vida decente" (p. 9). Mas, como anuncia o narrador, esse plano de vida acaba não dando certo. Franz vai sofrendo uma tripla derrota, que resumo aqui com as minhas palavras: 1) Como vendedor ambulante, ele é enganado por um colega. 2) Ao participar da ação de uma quadrilha, sem ter noção disso, ele é atirado por um falso amigo para fora de um carro, perdendo com isso o braço direito. 3) A sua namorada, que sempre lhe foi fiel, é assassinada por esse mesmo falso amigo. No final, Franz é internado num manicômio, onde vive oscilando entre um estado de catatonia e de inconsciência. Aparece-lhe então a figura alegórica da Morte, que lhe explica quais foram as causas de sua derrota: a ingenuidade e a soberba, o atrevimento misturado com a covardia, e uma fraqueza geral. O personagem de Franz morre, e é substituído por um novo protagonista chamado Franz Karl, moralmente "endireitado" e que trabalha numa fábrica como porteiro. $\mathrm{O}$ prólogo conclui com uma frase moralizante, típica das antigas narrativas populares: “Observar e ouvir isto valerá a pena para muitos que, como Franz Biberkopf, habitam uma pele humana e aos quais acontece o mesmo que a ele".

Para o leitor poder ter, desde o início, uma visão de conjunto da história do protagonista, eis

\section{Um breve resumo da história de Franz Biberkopf}

Prólogo (p. 9-10):

O narrador explica que se trata de uma história moralizante.

Io Livro (p. 11-47):

Franz Biberkopf (FB) sai da prisão após quatro anos. Ele procura reorientar-se na metrópole de Berlim. Propõe-se levar daqui em diante uma vida decente.

IIo Livro (p. 47-114):

Como ganhar a vida? FB vende jornais nazistas, embora não tenha nada contra os judeus. Por causa da suástica que ele usa, é provocado por militantes comunistas.

IIIo Livro (p. 115-132):

lun (1915), sobre a China; Manas (1927), sobre a Índia; e a chamada "Trilogia do Amazonas" (1937/38), composta pelos livros Das Land ohne Tod, Der blaue Tiger e Der neue Urwald. 
Conhece Lüders (L), um desempregado. F lhe conta como ganhou 20 marcos de uma viúva. L vai lá e extorque dinheiro dela. F percebe que foi enganado e rompe com $\mathrm{L}$.

IVo Livro (p. 133-182):

F frequenta bares e vive cochilando e bebendo. É a época da grande inflação na Alemanha. $\mathrm{F}$ precisa de dinheiro, mas não consegue ajuda.

Vo Livro (p. 183-243):

F continua vendendo o jornal nazista. Num boteco, conhece Reinhold (R) que ele admira. Junto com $\mathrm{R}$ e uma quadrilha participa de um roubo. Na fuga, $\mathrm{R}$ atira $\mathrm{F}$ para fora do carro.

VIo Livro (p. 245-344):

F recebe ajuda do casal Herbert e Eva. Submetido a uma cirurgia, tem um braço amputado. Eva arruma para F uma namorada, Mieze, que lhe é fiel e trabalha para ele como prostituta.

VIIo Livro (p. 345-406):

F participa de mais um roubo da quadrilha chefiada por Pums. Ele gaba-se com Mieze diante de R. Este marca um encontro com Mieze e a assassina.

VIIIo Livro (p. 407-470):

Desentendimento na quadrilha de Pums: $\mathrm{R}$ é denunciado. Numa batida da polícia nos botecos, F é preso.

IXo Livro (p. 471-521):

F é internado num manicômio e está definhando. A figura alegórica da Morte lhe explica quais foram as causas da sua derrota. FB morre, e surge um novo protagonista, de nome Franz Karl, moralmente "endireitado".

\section{Introdução ao ambiente da Metrópole}

Ao acompanhar os passos do protagonista Franz Biberkopf, somos introduzidos ao espaço central do enredo: Alexanderplatz, a praça que simboliza a capital alemã e passa a ser a super-personagem do livro. De lembrar que Berlim, no final dos anos 1920, com quatro milhões de habitantes, era, depois de Nova York, Londres e Paris, a quarta maior cidade do mundo.

No segundo dos nove capítulos ou "livros", a cidade de Berlim é apresentada graficamente por dez ícones (além do emblema principal, que 
é o Urso): Comércio e indústria; Limpeza e transportes urbanos; Serviço de saúde; Construção subterrânea; Arte e educação; Trânsito; Caixa econômica e Banco municipal; Companhia de gás; Corpo de bombeiros; e Finanças e impostos. É nesse espaço urbano, de organização complexa e, ao mesmo tempo, com características labirínticas e caóticas, que as pessoas precisam se orientar. Pois é aqui que elas têm que viver e sobreviver, o que significa: trabalhar para ganhar o dinheiro necessário para o seu sustento.

Existe uma correspondência latente entre o nome do protagonista Biberkopf = "Cabeça de Castor" - e a super-protagonista, que é a "Capital" ou "Cabeça do país"; ambos sendo derivados do latim caput. O castor representa o animal que constrói e ao mesmo tempo destrói, desmonta e monta. Com isso, é um ser que simboliza também a Alexanderplatz como canteiro de obras, o que ela foi, de fato, naquele final dos anos 1920: "Na Alexanderplatz, estão quebrando a rua para o metrô. Caminha-se sobre tábuas" (p. 135). E mais adiante diz o texto: "Brumm, brumm, moureja o bate-estacas a vapor diante do [restaurante] Aschinger na Alex. Tem a altura de um andar e crava as estacas no chão como se fossem nada" (p. 185). Com a onomatopeia "brumm, brumm", o narrador reforça o fascínio que a técnica moderna, representada aqui pelo bate-estacas que domina e subjuga o material, exerce sobre os transeuntes: "Ali, homens, mulheres e sobretudo os jovens ficam parados, contentes de ver como aquilo funciona perfeitamente: zás, a viga leva um golpe na cabeça" (p. 185).

Um canteiro de obras é também o romance no qual está descrita essa cena. Muito apropriadamente, Walter Benjamin observa em sua resenha que "o princípio estilístico desse livro é a montagem". E "a verdadeira montagem", que "se baseia no documento", "faz explodir o 'romance', estrutural e estilisticamente, e abre novas possibilidades, de caráter épico". ${ }^{5}$ Quais são - além do já referido conjunto de ícones mostrando a capital alemã como um complexo network de serviços administrativos, industriais, comerciais e culturais, e da caracterização de Alexanderplatz como canteiro de obras - os demais materiais e as técnicas de construção utilizados por Döblin em sua montagem da fisionomia da metrópole?

Um fator importante é o registro das múltiplas impressões sensoriais que o ambiente urbano causa nos habitantes da metrópole: a circulação de milhares e milhares de pessoas, o agito e o barulho do trânsito, os anúncios comerciais, os chamados dos jornais, a propaganda política, as histórias de acidentes e escândalos e as músicas de sucesso. Além da descrição de algumas moradias, o narrador focaliza sobretudo os botecos como lugares de encontros e conversas entre as pessoas. Muito importantes são também os meios de comunicação de massas. Através de notícias da imprensa e trechos de discursos políticos, o romance traça um retrato da capital alemã

5 “Crise do romance: Sobre Berlin Alexanderplatz, de Döblin”, p. 56. 
como lugar de graves problemas sociais e de acirradas lutas ideológicas e partidárias. Um lugar emblemático para mostrar a metrópole como lugar de perigo e de violência é também a descrição do matadouro, sugerindo analogias entre o destino dos animais que são abatidos e dos soldados que são enviados para os campos de batalha como "material humano" a ser desgastado. A grande cidade é associada também à "Grande Puta Babilônia". E, não por último, ela é o lugar onde circulam todos os tipos de linguagem: desde os gritos dos animais e as vozes das crianças, passando por canções populares e falas tipicamente berlinenses, até citações de obras literárias, versículos da Bíblia e expressões científicas, artísticas e filosóficas. Com essa quantidade enciclopédica de informações, o escritor transforma a sua obra numa oficina e num laboratório de linguagem, um dispositivo para perceber a metrópole moderna em toda a sua complexidade.

Alfred Döblin, que foi morar em Berlim a partir de seus dez anos, conhecia perfeitamente essa cidade e seus habitantes, sobretudo a parte central e a zona Leste, onde se concentrava a população operária. Vejamos mais de perto alguns dos elementos da topografia e da composição da obra.

\section{Nos botecos:}

\section{conversas sobre momentos decisivos da política e da história alemã}

Muitos dos episódios de Berlin Alexanderplatz passam-se em botecos. Estes costumam ser fundamentais como lugares de encontro para os habitantes da cidade e também para o nosso Franz Biberkopf. Aqui estabelecem-se contatos, travam-se conversas, iniciam-se namoros, discutem-se negócios e outros assuntos, planejam-se crimes (como acontece em diversos capítulos do livro), e também se pode ter uma ideia de como era a atmosfera política na República de Weimar.

Num dos botecos ocorre um confronto ideológico, que era típico para aqueles anos por volta de 1928 e 1929: o enfrentamento entre militantes da extrema direita e da extrema esquerda. Para ganhar dinheiro, Franz vende jornais, no caso, Der Völkische Beobachter (O Observador do Povo), que era publicado pelo Partido Nacional-Socialista. Por causa de sua braçadeira com a suástica, Franz é provocado, num dos botecos, por um grupo de militantes comunistas que cantam o hino da "Internacional" ( $\mathrm{p}$. 97). Franz replica com a canção nacionalista "A Guarda do Reno": "Ressoa um brado como um trovão, o retinir de espadas e o embate das ondas: Ao Reno, ao Reno, o Reno alemão, que queremos todos guardar! [...]" (p. 100).

Essas canções políticas estabelecem uma ligação entre os dois eixos de construção da obra: a história de Franz Biberkopf e a história alemã, representada por Alexanderplatz. O nome dado a essa praça, em 1805, foi uma homenagem ao Czar Alexandre I, que governou a Rússia de 1801 a 
1825, e cujo exército derrotou em 1812 a Grande Armée de Napoleão. A batalha decisiva, na travessia do rio Beresina, é evocada no capítulo final da obra de Döblin. Com o referido confronto entre a canção "A Guarda do Reno" (escrita em 1840 e musicada em 1854) e o hino da Internacional (1871), são evocados os conflitos militares entre a Alemanha e a França. A fundação do Segundo Reich alemão ocorreu em 1871, após a vitória do exército dos vários estados alemães sobre as tropas francesas. É instrutivo lembrar a esse respeito um comentário crítico publicado em 1873 por Friedrich Nietzsche:

\begin{abstract}
Uma grande vitória é um grande perigo. [...] De todas as consequências prejudiciais que a última guerra contra a França trouxe, a pior seja talvez [...] o erro da opinião pública [...] que também a cultura alemã tenha vencido nessa guerra.. [...] Esse desvario é altamente nefasto [...], porque é capaz de transformar a nossa vitória numa completa derrota: na derrota ou mesmo extirpação do espírito alemão em prol do "Reich" alemão. ${ }^{6}$
\end{abstract}

Essas palavras de alerta, e mesmo proféticas, acabaram sendo faladas ao vento. Na opinião pública alemã, sobretudo na classe dominante e entre os militares, prevaleceu a ideia, reforçada a partir de 1888 pelo governo do Imperador Guilherme II, de que para o Reich alemão teria chegado o momento de começar a luta para "tornar-se uma potência mundial". 7 Neste contexto, vem ao caso citar a expressão "den dicken Wilhelm rausbeißen", que foi traduzida por "contar bravatas", e que significa literalmente "bancar o balofo Guilherme". Diz Reinhold sobre Franz: "esse tonto, o atrevido, com aquele único braço, contando bravatas" (p. 371). Com a caracterização de Franz Biberkopf por meio do modo irônico com o qual os berlinenses se referiam ao rei da Prússia, Friedrich Wilhelm II (1786-1799), que tinha fama de paspalhão, Döblin conecta mais uma vez a trajetória do seu protagonista com a história da Alemanha.

Durante as conversas que Franz mantém nos botecos com seus antigos companheiros, são evocados também alguns acontecimentos históricos que acabaram levando à criação da República de Weimar e influíram decisivamente no seu destino. Antes de mais nada: a Guerra Mundial de 1914-1918, que foi perdida pela Alemanha, uma derrota que repercutiu traumaticamente na população do país. O narrador evoca as batalhas de Langemarck (1914) e do Chemin des Dames (1917): "estrondo de canhões, estouro de granadas de mão, fogo cerrado"; "as trincheiras soterradas, sepultados os soldados" (p. 508) E um companheiro de trabalho de Franz lhe faz relembrar a situação deles nos campos de batalha: “Eu

\footnotetext{
${ }^{6}$ F. Nietzsche, Unzeitgemäße Betrachtungen. Stuttgart: Alfred Kröner Verlag, 1964, p. 3. Tradução: W.B.

${ }^{7}$ Cf. Fritz Fischer, Griff nach der Weltmacht: Die Kriegszielpolitik des kaiserlichen Deutschland 1914/18, Düsseldorf: Droste Verlag, 2009 (1ª ed., 1961).
} 
conheço você de longa data, desde Arras e Kowno" (batalhas de 1917). "Nós simplesmente não conseguimos nada" [...], não havia disciplina. [...] Eu saí correndo da trincheira e você junto comigo". Essa fuga, segundo ele, ocorreu "porque fomos traídos, Franz, em 1918 e 1919, pelos chefões, que trucidaram a Rosa e o Karl Liebknecht" (94).

O argumento da traição, dos alemães por alemães, foi usado tanto pela ideologia da direita quanto pela esquerda. Segundo o Comando Supremo das Forças Armadas, o exército alemão não foi vencido nos campos de batalha pelas tropas inimigas, mas "apunhalado pelas costas" por militantes do Partido Democrático Social e comunistas. Os militantes de esquerda, por outro lado, como o referido companheiro de Franz, atribuíram a sua derrota aos chefões capitalistas, aliados dos militares e dos grupos paramilitares. A um desses grupos pertenciam os assassinos dos líderes comunistas Rosa Luxemburg e Karl Liebknecht, que organizaram em janeiro de 1919 com o grupo Spartakus uma revolta contra o governo, predominantemente burguês, da incipiente república, criada a partir da Revolução de Novembro de 1918. Ao longo de toda a década de 1920, a política interna na Alemanha foi fortemente determinada pelas organizações paramilitares: Freikorps, Stahlhelm, a S.A. nazista, e a Rotfront comunista.

\section{Através dos jornais: uma imersão na atmosfera da República de Weimar}

Complementando as conversas nos botecos, também as notícias da imprensa proporcionam um mergulho na atmosfera social e política da República de Weimar. Depois de ter sido malsucedido como vendedor ambulante, Franz Biberkopf, postado na Alexanderplatz, ganha o seu sustento com a venda do jornal Der Völkische Beobachter. É por mera necessidade financeira, não por motivos ideológicos, como observa ironicamente o narrador, que caracteriza a ingenuidade política do protagonista nestes termos: "Franz não tem nada contra os judeus, mas é a favor da ordem. Pois é preciso haver ordem no paraíso, isto qualquer um tem de reconhecer. E o Capacete-de-Aço [a organização paramilitar Stahlhelm] é uma coisa e tanto" (p. 89). Através de várias citações de notícias de jornais, montadas na narrativa, são apresentadas amostras da ideologia e da propaganda nacional-socialista:

Enquanto são escritas estas linhas, acontece a audiência de um processo contra os cavaleiros da Bandeira do Reich que [...] atacaram um punhado de nacional-socialistas, surrando-os e matando de maneira brutal o nosso companheiro de partido Hirschmann. [...] Federalismo verdadeiro é antissemitismo, luta contra o judaísmo [...]. Até a abertura da reunião, a nossa vigorosa banda da S.A. [a Sturm-Abteilung, tropa de choque nazista] 
alegrava o público com a briosa execução de marchas e melodias ligeiras. (p. 89-90)

As consequências que a guerra perdida e o Tratado de Versalhes, assinado em junho de 1919, tiveram para a situação econômica da Alemanha nos anos subsequentes são assim resumidas por um companheiro operário de Franz:

Quatro anos depois de 1918, estive em Berlim. [...] Tivemos inflação, dinheiro de papel, milhões, bilhões, nada de carne, nada de manteiga, pior do que antes [...]. Não havia nada. [...] Só andamos por aí e roubamos batatas dos camponeses. (p. 92)

Uma das manchetes citadas - estamos no início de 1928 - é esta: "Alarme de crise no Reichstag, fala-se de eleições, em março, provavelmente abril; qual será o rumo, Josef Wirth" (p. 190). O referido político, do Partido do Centro, tinha sido chanceler da República, de maio de 1921 a novembro de 1922. Ele saiu do cargo, porque seu engajamento no sentido de cumprir as exigências do Tratado de Versalhes causou um pesado endividamento ao Estado alemão e a hiperinflação de 1923, que foi traumática para o povo. Desde o começo de 1928, o número de desempregados na Alemanha aumentou cada vez mais. $O$ narrador observa: "Krupp deixa seus aposentados morrerem de fome, um milhão e meio de desempregados, em 15 dias houve um crescimento de 226.000" (p. 105). Como é sabido, nas grandes cidades alemãs daquela época era comum encontrar pessoas que carregavam cartazes dizendo: "Procuro trabalho. Faço qualquer coisa". Era uma situação histórica, na qual a confiança num estado de justiça social estava profundamente abalada e no qual se aguçaram os confrontos entre os militantes da extrema esquerda e da extrema direita.

A referida notícia sobre novas eleições no parlamento alemão e as lutas partidárias é seguida, na mesma frase, por uma notícia sobre um crime cotidiano: “assalto na Tempelherrenstrasse” (p. 190). Esse tipo de justaposição, de notícias sobre "crimes comuns", tais como aparecem todo dia nas páginas policiais, com informações sobre o que se passa nas altas esferas políticas é um procedimento estratégico de composição na obra de Döblin. De fato, em 1929, quando termina a história de Franz Biberkopf e quando o romance foi publicado, o crime na Alemanha não se limitava à ação de delinquentes praticando roubos e assaltos a residências, estabelecimentos comerciais, bancos etc. - crimes que as instâncias policiais e jurídicas estavam preparadas para combater. A referida crise nas instituições governamentais, fortemente agravada a partir de 1929 pelo crescente desemprego, causado pela crise econômica mundial, foi 
aproveitada por um bando de criminosos que se preparava para conquistar o poder político no país.

Mas vejamos primeiro como o indivíduo Franz Biberkopf é atraído para dentro do mundo do crime.

\section{Dos crimes comuns, noticiados na página policial, ...}

Como sobreviver na metrópole? Como ganhar dinheiro? Esta pergunta se coloca, de forma reiterada, também para o protagonista:

Franz Biberkopf sai à procura, é preciso ganhar dinheiro, sem dinheiro o homem não vive. (p. 62)

Franz Biberkopf marcha pela Rosenthaler Platz, está contente e diz: [...] preciso ganhar dinheiro, [...] tenho de arranjar dinheiro.

Vocês teriam de ver Franz Biberkopf, como foi à caça de dinheiro. (p. 274)

Depois de suas experiências como vendedor de quinquilharias e de jornais, abre-se para Franz ainda uma terceira possibilidade. Num dos botecos, um lugar de encontro dos comerciantes de frutas e de gado, ele chega a conhecer o Reinhold e o Sr. Pums, que é chefe de uma quadrilha, o que Franz não sabe. Como, nesse dia, um dos bandidos não compareceu, Pums faz uma proposta: "O senhor vai no lugar dele, Biberkopf. [...] Às nove horas precisamos pegar a mercadoria. [...] Hoje é domingo, e o senhor não tem mesmo o que fazer. Compenso suas despesas e ainda lhe pago um extra" (p. 234). Franz aceita.

O seu motivo principal não é a vantagem pecuniária, mas a vontade de estar ao lado de Reinhold, que faz parte da quadrilha e que Franz admira. O personagem de Reinhold - literalmente, "o puro e o atraente" -, cujo nome é irônico, não é nenhum exemplo de pureza moral, mas Franz "sentia-se fascinado por ele" (p. 199). A expressão original "fühlte sich mächtig von ihm angezogen" contém uma alusão ao opus magnum de Goethe, quando o Gênio, que aparece dentro de uma labareda, declara a Fausto: "Du hast mich mächtig angezogen" (Me atraíste poderosamente). ${ }^{8}$ Reinhold ganha a simpatia de Franz através de um "próspero tráfico de moças" (p. 200), ou seja, ele lhe passa uma série de mulheres, que ele já não quer mais: primeiro a Fränze, depois a Cilly, e em seguida a Trude. O resultado: "Com admiração e prazer, Franz agora sempre encontrava seu Reinhold" (p. 205).

${ }^{8}$ Cf. J. W. von Goethe, Fausto: uma tragédia, parte I, ed. bilíngue, São Paulo: Editora 34, 2004, p. 7071. 
Quanto à oferta de Pums, de Franz ajudar a "pegar a mercadoria", o nosso protagonista ingênuo percebe que se trata de um roubo, apenas quando já está inteiramente envolvido na ação criminosa. Quando os bandidos, fugindo de carro, são perseguidos por um outro carro, Reinhold atira Franz para fora do veículo. No capítulo final, o personagem de Reinhold é descrito pelo narrador com atributos diabólicos: "o fogo infernal lampeja-lhe dos olhos e crescem-lhe chifres na cabeça" (p. 502). E muito antes, quando Franz olha fascinado para o Reinhold e sorri para ele, enquanto este "não sorri nada", as ações futuras de Reinhold são anunciadas pelo narrador, que associa esse criminoso com a figura da Morte, através de uma canção popular da época barroca: "Existe uma ceifadeira, chamada Morte; do grande Deus vem o seu poder. Hoje afia a foice, que já corta muito melhor; não tardará a ceifar, vamos ter que suportar" (p. 208).

Os crimes cotidianos comuns - roubos, assaltos e outras ações violentas -, noticiados na página policial dos jornais, com vários exemplos citados em Berlin Alexanderplatz, aparecem diante do pano de fundo de uma grave crise política.

\section{... aos crimes políticos, que podem decidir o rumo de um país}

A respeito do crime na sociedade alemã, Alfred Döblin, no seu retrospecto de 1932, informa:

Minha atividade profissional como médico proporcionou-me contatos frequentes com criminosos. Alguns anos atrás trabalhei também num centro de observação para infratores. Advém disso muita coisa interessante e digna de ser mencionada. E quando encontrava essas pessoas e outras semelhantes, do lado de fora, adquiria então uma imagem singular da nossa sociedade: não existe nela uma fronteira rigidamente detectável entre elementos criminosos e não-criminosos; em todas as camadas possíveis a sociedade [...] está subvertida pela criminalidade. (p. 523)

De fato, especialmente naqueles anos entre 1929 e 1932 - quando, em consequência da crise econômica mundial, o número de desempregados na Alemanha subiu para o número alarmante de seis milhões de pessoas , um bando de criminosos conseguiu, por meio de discursos demagógicos e ações de grupos paramilitares, assumir o poder político no país. Em 30 de janeiro de 1933, o chefe desse bando, Adolf Hitler, foi nomeado chanceler do Reich. Como uma visão divinatória desse país que estava caminhando para a ditadura aparece esta observação sarcástica do narrador: "O Reich alemão é uma república, e quem não acredita nisso, recebe um golpe na nuca" (p. 304). 
Um estudo que complementa as informações de Berlin Alexanderplatz sobre a presença das ideias de Hitler na Alemanha daquela época é o livro de Hans Ulrich Gumbrecht, In 1926: living at the edge of time (1997). ${ }^{9}$ Ele descreve como Hitler, em Mein Kampf (1926), mostrou compaixão com “a trágica miséria dos operários" ${ }^{10}$ Nessa situação, argumenta Hitler, o povo deve confiar no "instinto de preservação da espécie", no sentido de um darwinismo social, e nos "poderes supremos". O racismo é justificado por ele como "lei da natureza" e "vontade de Deus". ${ }^{11}$ A tarefa mais importante do Líder, que se considera um gênio e um profeta, é "colocar as massas em movimento" ${ }^{12}$ Como chefe político, ele até justifica os crimes, contanto que sejam cometidos "em nome da nação":

Anunciar e liderar uma "guerra de extermínio" na esfera pública, cometer assassinato em nome da nação - estas são opções que nascem do colapso da relação entre o indivíduo e a sociedade. Se o fascínio pelo assassinato é o sintoma mais óbvio da desintegração da ordem, o papel do líder político carismático como promotor da síntese entre a individualidade e a coletividade se torna a solução mais amplamente aceita para essa crise. Líderes assim têm o poder de declarar o assassinato como legítimo. ${ }^{13}$

\section{Amputação e anestesia}

Como e porque Franz Biberkopf perdeu o seu braço direito, é um enigma tanto para o casal que lhe ajuda, Herbert e Eva, quanto para a sua namorada Mieze, uma vez que Franz não denuncia o perpetrador Reinhold, que ele continua admirando. Mieze fica sabendo do acontecido apenas por parte do próprio Reinhold durante um passeio na floresta, sendo logo em seguida assassinada por ele:

Uma vez Franz ficou de tocaia lá onde tínhamos um trabalho. E ele diz que não vai participar de nada, que é um homem decente. [...] Digo então que ele tem que ir junto com a gente. E ele tem que ir junto no carro, e eu ainda não sei o que fazer com o sujeito, sempre falou demais, então lá vem um carro atrás de nós e penso, agora vê se toma cuidado rapaz, você com essa fanfarronice de ser decente. E fora do carro. Agora você sabe onde foi parar o braço dele. (p. 402-403)

Depois de Franz ter sido levado pelos seus amigos Herbert e Eva para uma clínica, ele foi submetido a uma cirurgia: “O braço direito é amputado à altura da articulação do ombro" (p. 253). Com o estado da

\footnotetext{
${ }^{9}$ H. U. Gumbrecht, Em 1926: vivendo no limite do tempo; tradução de Luciano Trigo, Rio de Janeiro e São Paulo: Record, 1999.

${ }^{10}$ Cf. Gumbrecht, 1999, p. 397.

${ }^{11}$ Cf. Gumbrecht, 1999, p. 351 e 323.

${ }^{12}$ Cf. Gumbrecht, 1999, p. 343 e 435.

${ }^{13}$ Gumbrecht, 1999, p. 42-43.
} 
anestesia, que é necessária para uma amputação, o protagonista já tinha se familiarizado antes. "Biberkopf anestesiado": assim começa um subcapítulo do $4^{\circ}$ livro, quando Franz, após ter sido enganado por Otto Lüders, se retira e não quer ver mais nada, ficando "sempre deitado no quarto, e nada além de beber, cochilar e cochilar!" (p. 141). - A amputação e a anestesia do protagonista de Berlin Alexanderplatz tornam-se histórica e politicamente significativas, a posteriori, quando lemos paralelamente um relato sobre a Alemanha escrito em 1934 pelo etnólogo Curt Nimuendajú. Nascido em 1883 na cidade de Iéna, com o nome de Curt Unckel, ele emigrou em 1903 para o Brasil, onde se dedicou ao estudo da cultura dos indígenas, dos quais recebeu também o seu nome definitivo. Em 1934 fez uma breve estadia no seu país de origem, enviando de lá para o diretor do Museu Goeldi em Belém o seguinte relato:

O nacional-socialismo [= NS] exige do indivíduo que ele mergulhe no rebanho e odeia o individualismo do qual o cientista, por sua natureza, é o representante. Ciência ele só compreende e admite até onde ela se relaciona com os problemas do NS [...]. Causou-me pena o aspecto atual das vitrines das livrarias na Alemanha, porque elas formam um índice para o nível intelectual de um povo. Hoje são transformadas em meras agências de propaganda do NS, formando um contraste desagradável com o que se vê na Inglaterra, na Dinamarca e na Suécia. [...].

O NS me parece um fenômeno patológico. Permita-me uma comparação: Um homem recebe um ferimento grave numa perna. [...] Surge um médico, que leva o paciente para a mesa de operação, anestesiao, corta-lhe a perna e o homem está salvo. Muito bem. Mas o que não se concebe é que aquele médico queira agora sugerir ao paciente que doravante não só o seu estado normal, mas a condição ideal para ele seja a da anestesia ou da narcose. É o que Hitler está fazendo [com a Alemanha]. ${ }^{14}$

\section{Assassinato e guerra}

Voltando ao assassinato de Mieze, a namorada de Franz. Da palavra alemã Mordtat (assassinato) originou-se provavelmente a Moritat, que designa uma canção ou história exemplar, contendo um ensinamento moral. Como Walter Benjamin observou em sua resenha, Döblin estruturou os capítulos de sua obra com "anúncios no estilo das narrações populares moralizantes". 15 Depois do assassinato de Mieze por Reinhold,

\footnotetext{
${ }^{14}$ C. Nimuendaju, “Carta para Carlos Estevão, de 10/05/1934”, citada por Elena M. Welper, Curt Unckel Nimuendajú: um capítulo alemão na tradição etnográfica brasileira, dissertação de mestrado, Rio de Janeiro: UFRJ, 2002, p. 74.

${ }^{15}$ W. Benjamin, 1985, p. 57.
} 
numa floresta nos arredores de Berlim, a parte final do episódio é apresentada por meio de uma montagem de sons horripilantes:

$\mathrm{Uu}, \mathrm{u}, \mathrm{u}-\mathrm{uu}-\mathrm{u}$, a tempestade retorna, é noite. [...]

Agora é isso que acontece: rumm, rumm [...]. As árvores balançam para a direita e para a esquerda. Rumm, rumm. Mas não conseguem manter o ritmo [...], elas se vergam, estalam, estalejam, rangem, estouram, crepitam. Rumm faz a tempestade [...]. Uuuuu, u, uu [...]. Rumm, lá vem ela outra vez. Atenção, rumm, rumm, rumm, são bombas aéreas, ela quer arrancar a floresta, quer esmagar a floresta inteira.

As árvores gemem [...], elas racham [...], a vida é atingida, rumm, rumm [...]. Sou sua, venha, logo chegaremos, sou sua. Rumm, rumm. (p. 405-406)

A sequência dos verbos - "elas se vergam, estalam, estalejam, rangem, estouram, crepitam" - sugere uma onda de violência, representada pelas forças da natureza e o uso da moderna técnica bélica. $\mathrm{O}$ assassinato da moça é transportado para o ambiente de uma guerra: um ataque aéreo com bombas. E em baixo: um sussurro de palavras de amor, a saudade de ter um último encontro, antes que tudo acabe.

O fim da história mostra o novo personagem Franz Karl, assistindo, como porteiro de uma fábrica, a tropas que "passam marchando, com bandeiras e música e canto". Franz reflete: "Se houver guerra e eles me convocarem e eu não souber por quê [...], então terei culpa e será bem feito para mim". Por isso, ele se propõe: "Ficar desperto, olhos abertos, atenção [...], quem não despertar será ridicularizado ou aniquilado". Em meio ao rufar dos tambores e à marcha dos soldados, o narrador conclui: "Biberkopf é um pequeno operário. Sabemos o que sabemos, tivemos de pagar caro por isso" (p. 520-521).

"Marchamos para a guerra" (p. 521) está escrito na última frase do livro. Com isso, a história do indivíduo Franz Biberkopf e a história da Alemanha mais uma vez se entrelaçam. Tudo indica que o autor de Berlin Alexanderplatz tinha um nítido pressentimento de que a guerra de 19141918 teria continuidade numa segunda guerra mundial.

\section{Burrice de um indivíduo e burrice de um povo}

La sottise (a burrice), a palavra com a qual Baudelaire começa as Fleurs du Mal (1861), o mais importante livro de poemas sobre a metrópole moderna, poderia ser a epígrafe desta nossa leitura de Berlin Alexanderplatz. A moral da história de Franz Biberkopf é que ele próprio foi o principal culpado por toda a sua desgraça. Os personagens que opinam sobre ele, e também o narrador, que no final toma a palavra atrás da máscara da figura alegórica da Morte, concordam que o principal traço de caráter do 
protagonista é a sua burrice. Reinhold, numa conversa com Pums, traça de Franz este retrato:

Esse cara é um idiota [...], sempre rindo e sorrindo, ele é burro demais, deve ter um parafuso solto. [...] Imagine só, eu atiro o homem fora do carro, e ele reaparece aqui. [...] Não está regulando direito. Esse Biberkopf é um idiota, um paspalho. (p. 355-356)

Diante de tamanha burrice, com a qual Franz se apresenta diante dele, Reinhold se vê motivado a " brincar com esse cara”. A própria Mieze, que ama o seu Franz, nota nele os sintomas de burrice: "fizeram o Franz fazer o papel de bobo"; "o Franz é um bocadinho tonto, ele deixa que usem e abusem dele" (p. 377). O julgamento inicial do narrador, de que o protagonista é "arrogante e ingênuo" (p. 9), é confirmado e agravado no final pela figura da Morte:

Três vezes vergonha. Ela [Mieze] veio até junto de ti, era encantadora, te protegia, ficava alegre contigo, e tu? [...] Tu vais e te gabas com ela diante do Reinhold [...], atiçando-o com ela. Pensa bem se não é tu mesmo o culpado por ela não estar viva. E nenhuma lágrima derramaste por ela, que morreu por ti. (p. 497)

À limitação da inteligência - Franz se exibe com sua namorada diante do seu pior inimigo, motivando-o com isso a tirá-la dele acrescenta-se a pobreza do sentimento.

É instrutivo ler a história do tolo Franz Biberkopf da perspectiva de um discurso que o romancista Robert Musil proferiu em março de 1937 em Viena com o título "Sobre a burrice" . ${ }^{16}$ À luz desse texto pode ser realçada a sugestão subliminarmente presente no livro de Döblin, de que existe uma relação entre a burrice do indivíduo e o caminho de um povo rumo à burrice. De forma semelhante a Döblin, também Musil aponta para uma inter-relação entre a burrice e a soberba, especialmente no plano coletivo e político:

O homem público atuante, desde que está com o poder, diz [...] que foi escolhido por Deus e destinado a atuar na História. Isso se mostra sobretudo quando uma certa camada inferior da classe média - em termos intelectuais e morais - se manifesta protegido por um partido, uma nação ou uma seita e se sente autorizada a dizer "nós" em vez de "eu". ${ }^{17}$

Essa passagem é uma alusão ao partido de Adolf Hitler, que se preparou para anexar a Áustria ao Reich alemão, o que aconteceu em

\footnotetext{
${ }^{16}$ R. Musil, "Über die Dummheit", in: Gesammelte Werke, vol. 8, Essays und Reden, ed. por Adolf Frisé, Reinbek bei Hamburg: Rowohlt, 1978, p. 1270-1291. Tradução das citações: W.B.

17 Musil, 1978, p. 1275.
} 
março de 1938. No seu texto, Musil explica também que a burrice coletiva, quando entra em ação, assume a forma da bruteza. Em "pessoas, quando aparecem em grande quantidade", numa "maioria, que quer viver tudo o que deseja", ele observa "uma tendência de se permitir tudo o que lhes é proibido enquanto indivíduos". 18 Numa referência mais acima, ao livro Minha Luta, de Hitler, vimos que este considerou crimes como justificados, quando eram cometidos "em nome da nação". ${ }^{19}$ Musil conclui o diagnóstico de sua época com a observação de que "a burrice ocasional de um indivíduo pode facilmente se transformar numa burrice constitucional de todos", e acrescenta que "os exemplos para essa situação saltam aos olhos". ${ }^{20}$

Podemos encontrar exemplos concretos disso, consultando o Volume complementar, editado em 1935, sobre o regime nazista, e acrescentado aos 20 volumes anteriormente publicados da enciclopédia Der Große Brockhaus. ${ }^{21}$ No verbete "Brecht, Bertolt", encontra-se esta informação lacônica: "Escritor, expatriado em 1935, vive no exterior". E no verbete "Einstein, Albert", está escrito: "Foi demitido em 1933, como diretor do Instituto Kaiser-Wilhelm de Física, foi expatriado e desde então vive no exterior". - Assim, a Alemanha daquela época liquidou com a sua inteligência.

\section{Uma versão trapaceira do romance de formação?}

Walter Benjamin conclui a sua resenha de Berlin Alexanderplatz com esta observação: “A história desse Franz Biberkopf [...] é o estágio extremo, schwindelnd, último, mais avançado do antigo romance burguês de formação". $22 \mathrm{O}$ epíteto propositalmente ambíguo "schwindelnd" pode significar tanto "vertiginoso" quanto "trapaceiro". Com este segundo significado, a obra de Döblin acaba sendo avaliada de forma bastante severa. Também nas suas observações anteriores, Benjamin se manifesta de forma um tanto oscilante. Por um lado, ele acha que o fato de Döblin ter criado um segundo protagonista, de nome Franz Karl, foi "um grande lance artístico". Pouco depois, ele afirma: "No momento em que o herói ajuda a si mesmo, a sua existência não ajuda mais a nós, como leitores".

\footnotetext{
${ }^{18}$ Musil, 1978, p. 1276.

${ }^{19}$ Cf. supra, nota 13.

20 Musil, 1978, p. 1289. Neste contexto deve ser lembrada também a obra principal desse escritor: o romance épico Der Mann ohne Eigenschaften. Depois de Musil ter publicado, em 1931 e 1933, as partes I e II, ele trabalhou até o fim de sua vida (em 1942) na terceira parte do romance, à qual deu o título "Ins Tausendjährige Reich [Die Verbrecher]" - uma referência explícita ao "Império de Mil Anos", planejado por Adolf Hitler e seu bando de criminosos.

21 Der Große Brockhaus: Handbuch des Wissens in zwanzig Bänden, vol. 21, Ergänzungsband A-Z, Leipzig: 1935.

22 Cf. W. Benjamin, 1985, p. 57.
} 
Existe de fato uma ambiguidade na concepção dessa obra, que continua se filiando à tradição do romance de formação, mas ao mesmo tempo procura renovar esse gênero através da opção por uma epopeia moderna.

Se avaliamos a obra da perspectiva do romance de formação, existe uma contradição no modo como ela é construída. A liberdade de o leitor fazer a sua própria aprendizagem diante das dificuldades do protagonista de levar uma vida decente naquela época conturbada, é tolhida pelo narrador onisciente, que se coloca numa posição superior em relação ao protagonista e lhe ministra conselhos. Essa concepção de o personagem "ser conduzido", no sentido etimológico da e-duca-ção (do latim ducor, "eu sou conduzido"), não é uma "formação" (Bildung) e nem um "romance de formação" (Bildungsroman), no sentido de o indivíduo poder se desenvolver livremente, podendo cometer erros e aprender autonomamente a corrigir os seus erros.

Uma vez que o próprio Döblin optou por duas diferentes versões finais de sua história - na primeira, Franz Biberkopf morre; na segunda, ele renasce como o personagem Franz Karl - e que, além disso, na conferência "A construção da obra épica", ele defende a ideia de uma participação ativa do leitor, eu proponho uma terceira versão final para a ideia de formação, que não é trapaceira, mas é avançada, no sentido de desafiar o indivíduo a cuidar ele próprio de sua aprendizagem. Trata-se de um texto que tomo emprestado a um outro autor daqueles anos 1920. O narrador e o protagonista são idênticos. Trata-se de um indivíduo que, assim como Franz Biberkopf, se vê confrontado com a grande cidade moderna e não sabe qual é o caminho que ele deve tomar:

Eu ainda não sabia me orientar naquela cidade. Felizmente estava ali perto um guarda. Corri até ele e, já sem fôlego, perguntei pelo caminho. Ele sorriu e disse "É de mim que você quer saber o caminho?" "Sim", eu disse, "pois eu próprio não consigo encontrá-lo". "Desista", ele disse, "desista”, e virouse para o outro lado, como fazem pessoas que querem ficar a sós com a sua risada.

Certamente, todo o mundo conhece o autor que acabo de citar. O seu nome é idêntico ao do protagonista de Berlin Alexanderplatz: Franz. O sobrenome é: Kafka. ${ }^{23}$

\footnotetext{
${ }^{23}$ Cf. F. Kafka, “Gibs auf!”, in: Sämtliche Erzählungen, Frankfurt a. M.: S. Fischer, 1969, p. 410-411; “Desista!", in: Essencial Franz Kafka, tradução, seleção e comentários de Modesto Carone, São Paulo: Companhia das Letras, 2011, p. 183.
} 
Willi Bolle nasceu em 1944, perto de Berlim, veio para o Brasil em 1966, a fim de estudar este país à luz do romance Grande sertão: veredas. Em 1971, na Universidade de Bochum: doutorado sobre a evolução da técnica narrativa nos contos de J. G. Rosa (cf. Fórmula e fábula, 1973). Em 1984, na USP: livre-docência sobre Walter Benjamin e a cultura da República de Weimar. Desde 1990 é professor titular de Literatura Alemã na USP; depois de aposentado em 2009, exerce a função de professor sênior. Principais publicações: Fisiognomia da metrópole moderna (1994), grandesertão.br o romance de formação do Brasil (2004) e Amazônia: região universal e teatro do mundo (org., 2010). É também co-organizador de Cinco séculos de relações brasileiras e alemãs (2013) e Relações entre Brasil e Alemanha na época contemporânea (2015). 